\title{
GEOTHERMAL DRILLING IN AN ALPINE KARST AQUIFER AND ITS IMPACT ON DOWNSTREAM SPRINGS - A CASE STUDY FROM FINKENBERG, TYROL, AUSTRIA
}

\author{
GEOTERMALNO VRTANJE V ALPSKEM KRAŠKEM \\ VODONOSNIKU IN NJEGOV VPLIV NA DOLVODNE IZVIRE - \\ ŠTUDIJA PRIMERA FINKENBERG, TIROLSKA, AVSTRIJA
}

\author{
Rafael SCHÄFFER ${ }^{1, \star}$, Ingo SASS ${ }^{1,2}$, Claus-Dieter HELDMANN ${ }^{1}$ \& Dirk SCHEUVENS ${ }^{3}$
}

\begin{abstract}
UDC 556.33:550.822(436.6)

Rafael Schäffer, Ingo Sass, Claus-Dieter Heldmann \& Dirk Scheuvens: Geothermal drilling in an Alpine karst aquifer and its impact on downstream springs - A case study from Finkenberg, Tyrol, Austria

A borehole heat exchanger array was installed in an Alpine karst aquifer for the first time in Europe. It is composed of nine $400 \mathrm{~m}$ deep boreholes in the dolomitic marble of the Hochstegen Formation. New approaches were developed for this unprecedented application and potential risks were checked throughout the sinking of the initial exploratory wellbore. As Finkenberg is located in a tourist area, drilling operations had to be executed within only a few weeks. Several springs downstream from the drilling site are sources of drinking water and tap water supply. Given that the degree and distribution of the Hochstegen Formation karstification was unknown, a spring monitoring program was mandatory in order to obtain drilling permission from public authorities. A practicable and affordable spring monitoring program including several physical and chemical parameters was developed and implemented to document the potential impact of the drilling activities on the spring water. A temporary and locally limited impact of the drilling works on groundwater quality was detected by turbidity measurements. This paper reports the implementation of geothermal drilling in a karst aquifer with a focus on karstification as well as planning, implementation and the results of the spring monitoring program. Such a program can be recommended for comparable projects or questions, adapting the characteristic
\end{abstract}

\begin{abstract}
Izvleček UDK 556.33:550.822(436.6)
Rafael Schäffer, Ingo Sass, Claus-Dieter Heldmann \& Dirk Scheuvens: Geotermalno vrtanje v alpskem kraškem vodonosniku in njegov vpliv na dolvodne izvire - študija primera Finkenberg, Tirolska, Avstrija

$\mathrm{V}$ alpskem kraškem vodonosniku je bilo prvič v Evropi vzpostavljeno polje geosond. Vključuje devet $400 \mathrm{~m}$ globokih vrtin, izvrtanih v dolomitnem marmorju Hochstegenove formacije. Razvili smo nove pristope za to aplikacijo brez primere in potrdili morebitna tveganja $\mathrm{v}$ času potopitve prvotne raziskovalne vrtine. Ker je študijsko območje Finkenberg na turističnem območju, je bilo treba opraviti vrtanje $\mathrm{v}$ samo nekaj tednih. Več izvirov od mesta vrtanja so viri oskrbe s pitno vodo. Glede na to, da stopnja in porazdelitev zakraselosti Hochstegenove formacije nista bili znani, je bilo treba za pridobitev dovoljenja za vrtanje nujno opazovati izvire. Da bi dokumentirali vpliv vrtanja na izvirsko vodo, je bilo pri spremljanju izvirov treba upoštevati več fizikalnih in kemijskih parametrov. Zaznali smo občasen in lokalno omejen vpliv vrtanja na kakovost podzemne vode. V prispevku smo predstavili izvajanje geotermalnega vrtanja $\mathrm{v}$ kraškem vodonosniku s poudarkom na identifikaciji zakraselosti ter načrtovanju ter na izvedbi in spremljanju kakovosti voda na izviru. Tak program se lahko uporabi pri primerljivih projektih ali iskanju odgovorov na podobna vprašanja $s$ prilagojenim programom opazovanih parametrov in intervalov merjenja. Prav tako bi lahko povečal možnosti za pridobitev soglasja za geotermalne projekte na krasu in povečal ozaveščenost javnosti.
\end{abstract}

\footnotetext{
${ }^{1}$ Institute of Applied Geosciences, Chair of Geothermal Science and Technology, Technische Universität Darmstadt, Schnittspahnstrasse 9, 64287 Darmstadt, Germany, e-mail: schaeffer@geo.tu-darmstadt.de, sass@geo.tu-darmstadt.de, heldmann@geo.tu-darmstadt.de

${ }^{2}$ Darmstadt Graduate School of Excellence Energy Science and Engineering, Technische Universität Darmstadt, JovankaBontschits-Strasse 2, 64287 Darmstadt, Germany, e-mail: sass@geo.tu-darmstadt.de

${ }^{3}$ Institute of Applied Geosciences, Chair of Environmental Mineralogy, Technische Universität Darmstadt, Schnittspahnstrasse 9, 64287 Darmstadt, Germany, e-mail: dscheuvens@geo.tu-darmstadt.de

* Corresponding author
}

Received/Prejeto: 28.03.201 
parameters to be collected and the measurement intervals in consultation with the relevant authorities. It might also increase the chances of gaining approval for geothermal projects in karst and could enhance public acceptance.

Key words: Pneumatic down hole hammer drilling, Borehole heat exchanger, Groundwater monitoring, Turbidity, Hochstegen Formation.
Ključne besede: vrtanje s pnevmatskim kladivom, geosonda, spremljanje podzemne vode, motnost, Hochstegenova formacija.

\section{INTRODUCTION}

In Europe, shallow geothermal drillings in karst aquifers are not permitted in many cases or are only allowed with a high number of constraints (Butscher et al. 2011). In permission procedures, groundwater protection is frequently prioritised over renewable energy development and thereby also over climate protection. One important reason for this is a lack of experience and knowledge of the influence of geothermal drilling on karst aquifers. Other reasons are the risk of groundwater pollution, a change in groundwater properties or a reduction of groundwater resources (Milenic \& Vranjes 2014).

Due to their heterogeneity, karstified rocks can exhibit very different hydrogeological properties. The research and exploration of these formations is still challenging (Bakalowicz 2005; Goldscheider \& Ravbar 2010; Stevanović \& Milanović 2015). Comparatively high flow velocities and flow rates are the main reasons for the vulnerability of karst aquifers. Therefore, careful exploration is necessary before operations into the underground are begun. Conflicts of use are well known, for example between drinking water supply and geothermal energy utilization (Goldscheider et al. 2010).

For the first time a medium depth borehole heat exchanger (BHE) was installed in such a hydrologically sensitive and highly permeable karst aquifer in the Alps. Initially, an exploratory wellbore was drilled to a total vertical depth (TVD) of approximately $400 \mathrm{~m}$ to reduce the uncertainties. Well logs are given in Lehr and Sass (2014), and Sass et al. (2016a). The aim was to equip the exploratory wellbore with a BHE and additionally install eight $400 \mathrm{~m}$ deep drillings, featuring a total capacity of $1 \mathrm{GWh} / \mathrm{a}$ heat extraction and $400 \mathrm{MWh} / \mathrm{a}$ cooling (Sass et al. 2016a).

As Finkenberg is located in a tourist area, a very short construction period was permitted by the government. Hence, the drilling works had to be executed within three weeks in the low season to avoid inconveniences for the tourists. Therefore a fast drilling technique was preferred and two parallel working rigs were utilized. Pneumatic down hole hammer drilling was chosen due to the expected hard carbonate rocks. Although usually used in hard crystalline or consolidated rocks for shallow drilling, the limit of this drilling method is governed by the compressor air pressure (typically $2-2.4 \mathrm{MPa}$ ) and usually ends with a $240 \mathrm{~m}$ water column (Misstear et al. 2006). Here a drilling target depth of $400 \mathrm{~m}$ was reached with a higher pressure, marking the most recent limit of achievable drilling depth.

Several natural springs are located downstream from the borehole heat exchanger field. The farthest investigated spring is located in a horizontal distance of $750 \mathrm{~m}$ from the BHE field. The springs are used for different purposes. A monitoring program was implemented to determine effects of the geothermal drillings on spring water quality and quantity. Physical and chemical parameters were measured in defined intervals before, during and after drilling and the completion of the works.

\section{GEOLOGICAL OVERVIEW}

\section{TOPOGRAPHY}

The project area is located at Finkenberg within the Tuxertal (Tux Valley), a glacial trough (Wirsig et al. 2016), in the federal state of Tyrol, Austria. To the east, the valley floor declines rapidly from 1,060 $\mathrm{m}$ to 660 $\mathrm{m}$ a.s.l. and ends in the Zillertal (Fig. 1). The Tuxbach
(Tux Creek) has used this topographic gradient to cut an impressive deep gorge, $4 \mathrm{~km}$ long and up to $60 \mathrm{~m}$, into the valley floor. Here, the valley is framed in the north by the Penken massive (peak altitude of 2,095 $\mathrm{m}$ a.s.l.) and to the south by the Grinbergspitze $(2,867 \mathrm{~m}$ a.s.l.). 


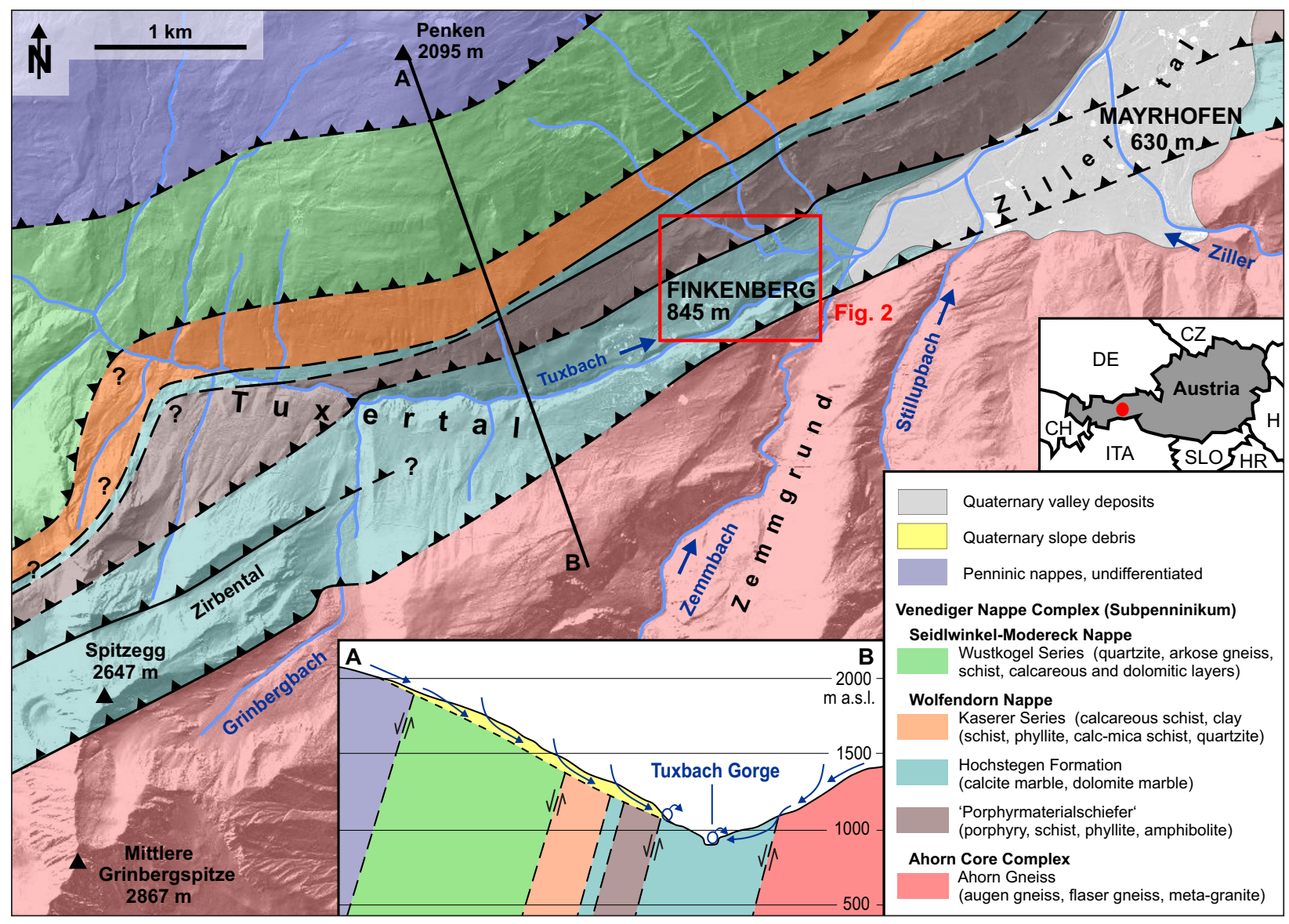

Fig. 1: Schematic and simplified geological map of the project area, modified after Rauch and Neuner (1993) as well as Geologische Bundesanstalt (2005). Only major nappe thrusts are shown. The conceptual profile illustrates the drainage of the lower Tuxertal. Relief shading was taken from Land Tirol (2017).

\section{GEOLOGY}

The study area around Finkenberg is located at the north-western margin of the Tauern Window, an exhumed nappe stack formed during the Alpine orogeny (Frisch 1979; Schmid et al. 2013). The recent exposure of the Tauern Window is the result of south-directed subduction of oceanic crust (Piemont-Liguria and Valais Ocean respectively; e.g., Schmid et al. 2013), subsequent collision of the southern European continental margin and the Austroalpine units of the Adriatic margin during the Oligocene, and final doming and exhumation associated with lateral extrusion during the Miocene. The collision stage formed an impressive nappe stack including a duplex structure in the core of the Tauern Window (Venediger Duplex). The Venediger Duplex comprises several nappe units consisting of Variscan orthogneisses and their host rocks and post-Variscan cover sequences. Miocene doming caused large-scale folding and the formation of two antiformal structures (sub-domes) in the western part of the Tauern Window. The northern limb of the northern antiform dips steeply to the north and is exposed in the Finkenberg area (Frisch 1968; Kurz et al. 1998).

In the study area (Fig. 1), the northern limb is represented by several nappes (from $\mathrm{S}$ to $\mathrm{N}$ : Ahorn Nappe, Wolfendorn Nappe, Seidlwinkl-Modereck Nappe, Glockner Nappe and Matrei Zone, Innsbruck Quartz Phyllite Nappe). The Ahorn Nappe consists of variably deformed orthogneisses (mainly augen gneiss) with an emplacement age of $335 \pm 1.5 \mathrm{Ma}$ (U-Pb zircon, Veselá et al. 2011). In the hanging wall of the orthogneisses the Jurassic Hochstegen Formation is exposed. According to different authors, the contact between both units was described as autochthonous, parautochthonous, or allochthonous (Frisch 1968; Thiele 1976; Frisch 1980). From base to top, the Hochstegen Formation comprises thin layers of quartzite, phyllite, and brownish marble, followed by a unchanging series of greyish-blue banded calcitic and dolomitic marbles. Micro-paleontological investigations of an outcrop in Finkenberg revealed an Upper Jurassic (Tithonian) age for the exposed marble (Kießling 1992; Kießling \& Zeiss 1992). 
In the hanging wall of the banded marble, a nappe contact separates the Hochstegen Formation from the Wolfendorn Nappe, the latter consisting, from base to top, of the Porphyrmaterialschiefer (Permo-Triassic volcanosedimentary sequence) (Beil-Gregorczyk 1988), a thin marble layer of the Hochstegen Formation, and calcite phyllites of the Kaserer Series (Thiele 1976) (probably Cretaceous). Further to the north and in a hanging wall position to the Wolfendorn Nappe, the Seidlwinkl-Modereck Nappe is exposed. The Seidlwinkl-Modereck Nappe comprises Permo-Triassic arkosic gneisses of the Wustkogel Series, flanked to the north and south by Triassic marbles.

To the north the nappe stack continues with calcite phyllites and quartzite of the oceanic Glockner Nappe and Matrei Zone (Upper Jurassic and/or Lower Cretaceous), and finally quartz phyllites of the Austroalpine Innsbrucker Quartz Phyllite Nappe (Paleozoic) in the uppermost position of the catchment area around Finkenberg.

At the northern margin of the Tauern Window, Miocene doming and exhumation of the nappe pile is associated with large-scale, steeply dipping mainly ductile sinistral shear zones. In the project area, the northernmost of these shear zones, the Ahorn Shear Zone, affects the rocks of the Wolfendorn Nappe as well as the units in the foot and hanging wall, respectively (Rosenberg \& Schneider 2008).

\section{HYDROGEOLOGY}

The lowest part of the Tuxertal is drained by the Tuxbach Gorge. Here the Hochstegen Formation strikes $\left(60^{\circ}\right.$ ENE) parallel to the valley and dips approximately $70^{\circ}$ NNW (Fig. 1). The underlying Ahorn Gneiss and the Porphyrmaterialschiefer in the hanging wall are effective aquicludes. The hydrogeological situation is different on both sides of the valley.

On the northern slope, low-grade metamorphic nappes are exposed. They are mainly composed of calcareous schist, schist, arkose gneiss, quartzite, calcareous phyllite and phyllite. These nappes are covered by post- and periglacial mass movements (Rauch \& Neuner 1993). Depending on the original material, the hydrogeological properties are different within the mass move- ment. In all cases, a spatially and temporally variable and continuous interflow drains the northern slope (Rauch \& Neuner 1993). Calcareous debris causes lime-saturation of the water. Therefore, the groundwater has low karstification potential when the Hochstegen marble is reached.

On the southern slope, low mineralized waters originating from the Ahorn Gneiss infiltrate the Hochstegen Formation (Sass et al. 2016b). The water is lime-unsaturated and cold. Consequently it possesses high karstification potential. Several karst phenomena are observable in the area, for example cavities below Spitzegg and in the Zirbental (a dry valley), ponors at the Grinbergbach, and karst springs and small caves within the Tuxbach Gorge (Fig. 1).

There are two recently gauged and officially catalogued caves in the lower Tuxertal (Spötl \& Schiffmann 2014). In the middle and upper part of the valley, however, almost 40 caves are known to be in the surroundings of the Höllenstein (Spötl 2009), $9 \mathrm{~km}$ southwest of Finkenberg, and in the region of the Olperer (Christian \& Spötl 2010; Cliff et al. 2010; Spötl \& Mangini 2010), about $15 \mathrm{~km}$ southwest of Finkenberg. The retreat of glaciers enabled the discovery of several caves in the recent past (Stummer \& Plan 2002; Spötl 2009).

In summary, at Finkenberg a high level of karstification is expected at the southern slope of the Tuxertal where the Hochstegen Formation acts as a karst aquifer. A low level of karstification is expected at the northern slope of the valley where the Hochstegen Formation is probably better described as a fissure aquifer (cf. profile in Fig. 1). In fact, the exploratory wellbore confirms that the marble of the Hochstegen Formation is karstified quite heterogeneously: either no or low karstification was found from the surface to a depth of $180 \mathrm{~m}$, moderate karstification from 180 to $310 \mathrm{~m}$ depth, followed by zones of high karstification from 310 to $400 \mathrm{~m}$ depth (Lehr \& Sass 2014). The maximum groundwater flow velocity was determined by using optical frequency domain reflectometry and resulted in $14 \mathrm{~m} / \mathrm{d}$ (Sass et al. 2016a). The increase of karstification with depth might be a result of two factors: firstly, the topographic gradient between Finkenberg and Mayrhofen, and secondly, the $70^{\circ}$ dip of the formation towards NNW.

\section{MONITORING OF SPRINGS}

\section{SCIENTIFIC AND LEGAL REASONS}

Six gravity springs are known downstream from the drilling location, in distances of approximately 95 to $750 \mathrm{~m}$ (Fig. 2, Tab. 1). The catchment areas are estimat- ed based on annual precipitation, groundwater recharge rates, average discharge, topography and geological conditions. Two springs are used for drinking water supply and the other springs provide water for domestic 
use. Hence, any impact on water quantity or quality induced by drilling and completion activities would have been unacceptable. The spring monitoring program was developed in consultation with the state of Tyrol water authorities and the Republic of Austria mining authorities. The program had the following purposes:

- to identify possible influences of drilling on the spring water;
- to document the duration and extent of any influences,

- data acquisition to define pressing action items.

Probable action items would have been an emergency water supply or an immediate stop of the drilling work. Nevertheless, owing to Austrian Mining Law (Bundeskanzleramt 1999 and later changes) a spring monitoring program was mandatory in order to obtain drilling permits.

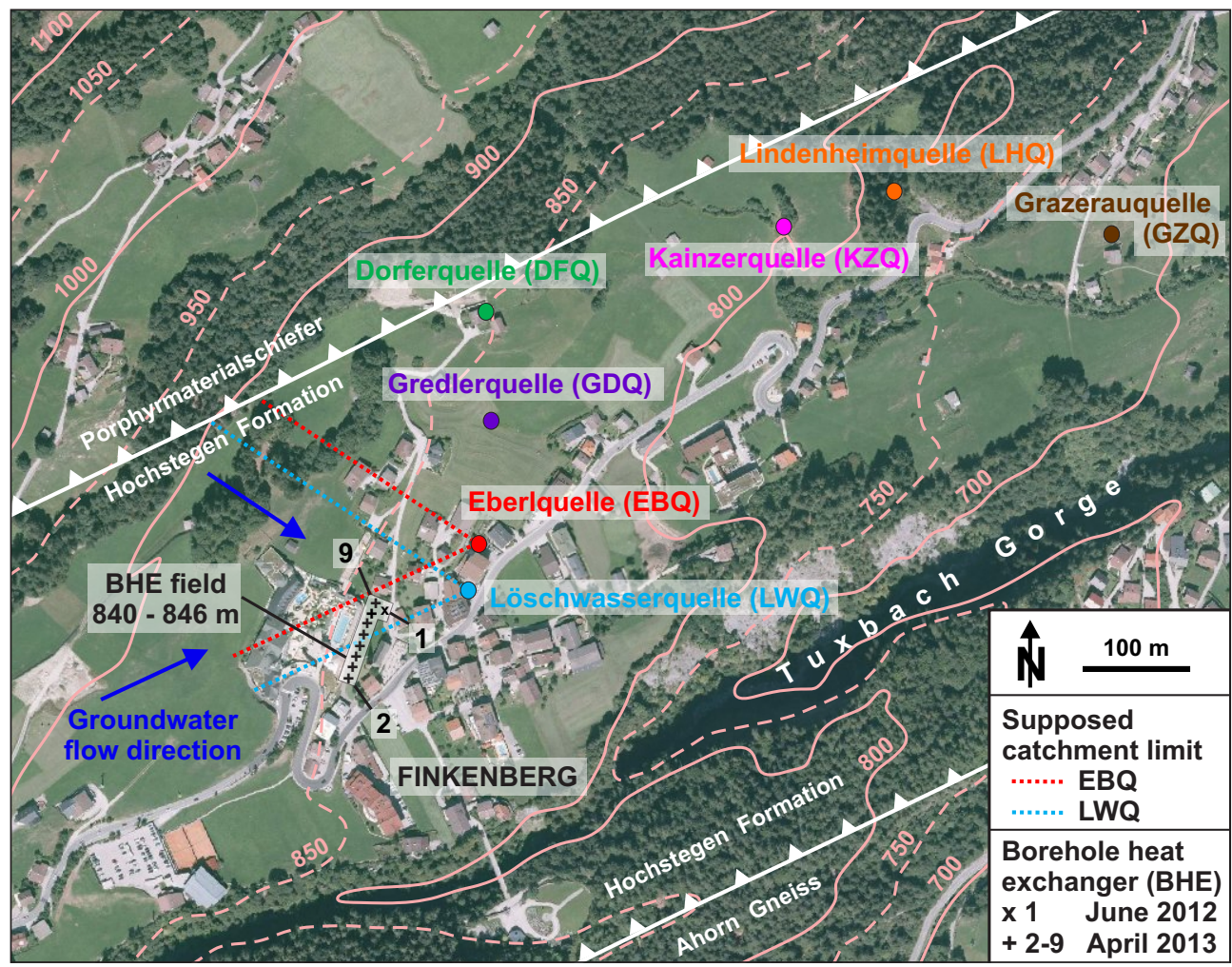

\begin{tabular}{|c|c|c|c|c|c|c|c|}
\hline Spring & DFQ & EBQ & GDQ & GZQ & KZQ & LHQ & LWQ \\
\hline Altitude (m a. s. I.) & 855 & 825 & 834 & 715 & 808 & 781 & 830 \\
\hline $\begin{array}{l}\text { Linear distance to BHE } \\
9(\mathrm{~m})\end{array}$ & 290 & 110 & 205 & 750 & 525 & 615 & 95 \\
\hline $\begin{array}{l}\text { Estimated catchment area } \\
\left(\mathrm{km}^{2}\right)\end{array}$ & $0.5-4$ & $0.01-0.1$ & $\begin{array}{c}0.05- \\
0.5\end{array}$ & $\begin{array}{l}0.05- \\
0.5\end{array}$ & $\begin{array}{c}0.05- \\
0.5\end{array}$ & $\begin{array}{c}0.001- \\
0.01\end{array}$ & $\begin{array}{c}0.04- \\
0.4\end{array}$ \\
\hline Temperature $\left({ }^{\circ} \mathrm{C}\right)$ & $\begin{array}{r}8.4 \\
9.0 \\
10.7\end{array}$ & $\begin{array}{r}8.8 \\
10.3 \\
14.0\end{array}$ & $\begin{array}{r}8.8 \\
9.6 \\
11.2\end{array}$ & $\begin{array}{r}8.0 \\
9.0 \\
10.2\end{array}$ & $\begin{array}{r}7.6 \\
8.6 \\
10.7\end{array}$ & $\begin{array}{r}6.3 \\
8.7 \\
14.1\end{array}$ & $\begin{array}{r}8.2 \\
10.2 \\
13.1\end{array}$ \\
\hline $\begin{array}{l}\text { Electrical conductivity } \\
\text { at } 25^{\circ} \mathrm{C}(\mu \mathrm{S} / \mathrm{cm})\end{array}$ & $\begin{array}{l}392 \\
405 \\
411\end{array}$ & $\begin{array}{l}430 \\
454 \\
479\end{array}$ & $\begin{array}{l}423 \\
426 \\
437\end{array}$ & $\begin{array}{l}460 \\
518 \\
549\end{array}$ & $\begin{array}{l}440 \\
448 \\
458\end{array}$ & $\begin{array}{l}408 \\
468 \\
520\end{array}$ & $\begin{array}{l}477 \\
489 \\
503\end{array}$ \\
\hline Discharge (L/s) & $\begin{array}{l}3.87 \\
6.93 \\
15.9 \\
\end{array}$ & $\begin{array}{l}0.10 \\
0.19 \\
0.52 \\
\end{array}$ & $\begin{array}{l}0.37 \\
0.81 \\
1.96 \\
\end{array}$ & $\begin{array}{l}0.38 \\
0.70 \\
1.18 \\
\end{array}$ & $\begin{array}{l}0.59 \\
0.88 \\
2.31 \\
\end{array}$ & $\begin{array}{c}0 \\
0.019 \\
0.068 \\
\end{array}$ & $\begin{array}{c}- \\
0.48 \\
-\end{array}$ \\
\hline Turbidity (FNU) & $\begin{array}{l}0.04 \\
0.37 \\
1.95\end{array}$ & $\begin{array}{l}0.15 \\
0.46 \\
1.68\end{array}$ & $\begin{array}{l}0.05 \\
0.30 \\
0.89\end{array}$ & $\begin{array}{l}0.09 \\
0.31 \\
1.02\end{array}$ & $\begin{array}{l}0.02 \\
0.28 \\
0.59\end{array}$ & $\begin{array}{l}0.17 \\
0.59 \\
2.61\end{array}$ & $\begin{array}{l}0.16 \\
9.75 \\
103\end{array}$ \\
\hline
\end{tabular}

Tab. 1: Characteristics of monitored springs, $a b$ breviations as defined in Fig. 1. Minimum, arithmetic mean and maximum values are given for temperature, electrical conductivity, discharge and turbidity. 


\section{MEASURING PROGRAM}

In addition to the six above mentioned springs, the Dorferquelle (DFQ), located about $290 \mathrm{~m}$ north and $10 \mathrm{~m}$ higher in altitude than the drill site, served as an unaffected reference spring (Fig. 2). From a legal perspective it was necessary to control certain parameters with defined critical values in the Austrian Drinking Water Ordinance (Bundeskanzleramt 2001), which is the conversion of the European Council Directive 98/83/EC (EC 1998) to the national legislation. The parameters are the concentrations of sodium, ammonium, fluoride, chloride, nitrite, nitrate and sulphate as well as turbidity, water temperature, $\mathrm{pH}$ and electrical conductivity. In order to facilitate the assent of the spring owners and to increase the public acceptance of the project, some other parameters were included. From a scientific perspective, temperature, electrical conductivity, turbidity and discharge are the most interesting parameters, due to their sensitivity and the difference between groundwater and drilling fluid.

The measuring program contained the following parameters to be recorded on-site: water temperature, electrical conductivity, $\mathrm{pH}$ and redox potential (all measured with the universal pocket meter Multi 340i from WTW), turbidity (measured with the turbidimeter 2100Qis from $\mathrm{HACH}$ ), and discharge.

Sporadic water sampling and on-site measurements took place in January, February and March 2013 to determine the natural and undisturbed conditions before the start of drilling operations. Daily measurements began one week ahead of construction works. Two drill rigs were used simultaneously. Drilling, completion and grouting of BHE no. 2 to 9 took place in the period from 8-26 April. During this time span, daily measurements were maintained. After completion of the construction two further samples were taken in May and one each in June, July and August.

Spring water was sampled to determine hydrochemical parameters in the laboratory. The concentrations of the cations $\mathrm{Li}^{+}, \mathrm{Na}^{+}, \mathrm{K}^{+}, \mathrm{NH}_{4}^{+}, \mathrm{Mg}^{2+}, \mathrm{Ca}^{2+}, \mathrm{Sr}^{2+}$ and of the anions $\mathrm{F}^{-}, \mathrm{Cl}^{-}, \mathrm{Br}^{-}, \mathrm{NO}_{2}^{-}, \mathrm{NO}_{3}^{-}, \mathrm{SO}_{4}^{2-}, \mathrm{PO}_{4}^{3-}$ were analysed by ion exchange chromatography (device "882 Compacts IC plus" by Metrohm). Due to the variability of the carbonate balance, the content of bicarbonate $\left(\mathrm{HCO}_{3}^{-}\right)$was determined in situ by titration. By measuring the electrical conductivity, a noticeable change in the hydrochemical composition could be noticed immediately in the field, without waiting for laboratory results.

Measurements and sampling were carried out on the outlet pipes of the springs. In the case of the Löschwasserquelle (LWQ) the design of the spring tapping is an outlet pipe, which ends above an $80 \mathrm{~m}^{3}$ underground basin. The outlet is accessible by divers only. Therefore, the discharge water of LWQ could only be measured once at the beginning of monitoring and once at the end. All other measurements at that particular spring were made at the basin overflow pipe.

\section{RESULTS}

\section{TURBIDITY}

Preliminary investigations showed that turbidity values in the seven monitored springs are below 3 FNU (Fig. 3A). Consequently, values below 3 FNU are regarded as spring water turbidity natural background. Comparative measurements in the Tuxbach and its tributaries resulted in turbidity values of 1 to 75 FNU. Strong precipitation events or snow melt delivered higher amounts of sedimentary particles which caused an increase of the turbidity of up to 875 FNU. This effect was not detected in the springs. The drilling mud back flow measured at the preventer was out of the effective range of the turbidity sensor of 1000 FNU. Therefore, the drilling mud features significantly higher values.

Compared to all other monitored parameters, turbidity is the best suited indicator of a hydraulic contact between boreholes and spring, due to the span of at least three magnitudes. Noticeable turbidity values were only found in Löschwasserquelle (LWQ): a first peak of 31 FNU on 12 April, a second peak of 103 FNU on 16 April, and a third peak of 10 FNU on 22 April (Fig. 3A). Eberlquelle (EBQ) shows two small peaks within the drilling period. These fit chronologically with the first and third peaks of LWQ, but are one magnitude lower. On 17 April, Dorferquelle (DFQ) and Gredlerquelle (GDQ) exhibited turbidity maxima of $1.95 \mathrm{FNU}$ and $0.89 \mathrm{FNU}$, respectively. All other springs do not show conspicuous turbidity values.

\section{WATER TEMPERATURE AND DISCHARGE}

In general, the water temperatures of the springs reach a minimum of 8.2 to $9.6{ }^{\circ} \mathrm{C}$ in February or March and rise 




Fig. 3: Spring monitoring results from January to August 2013: A) logarithmic plot of water turbidity, B) spring water temperature and averaged daytime temperature at Mayrhofen, C) logarithmic plot of discharge with cumulated daily precipitation at Mayrhofen 


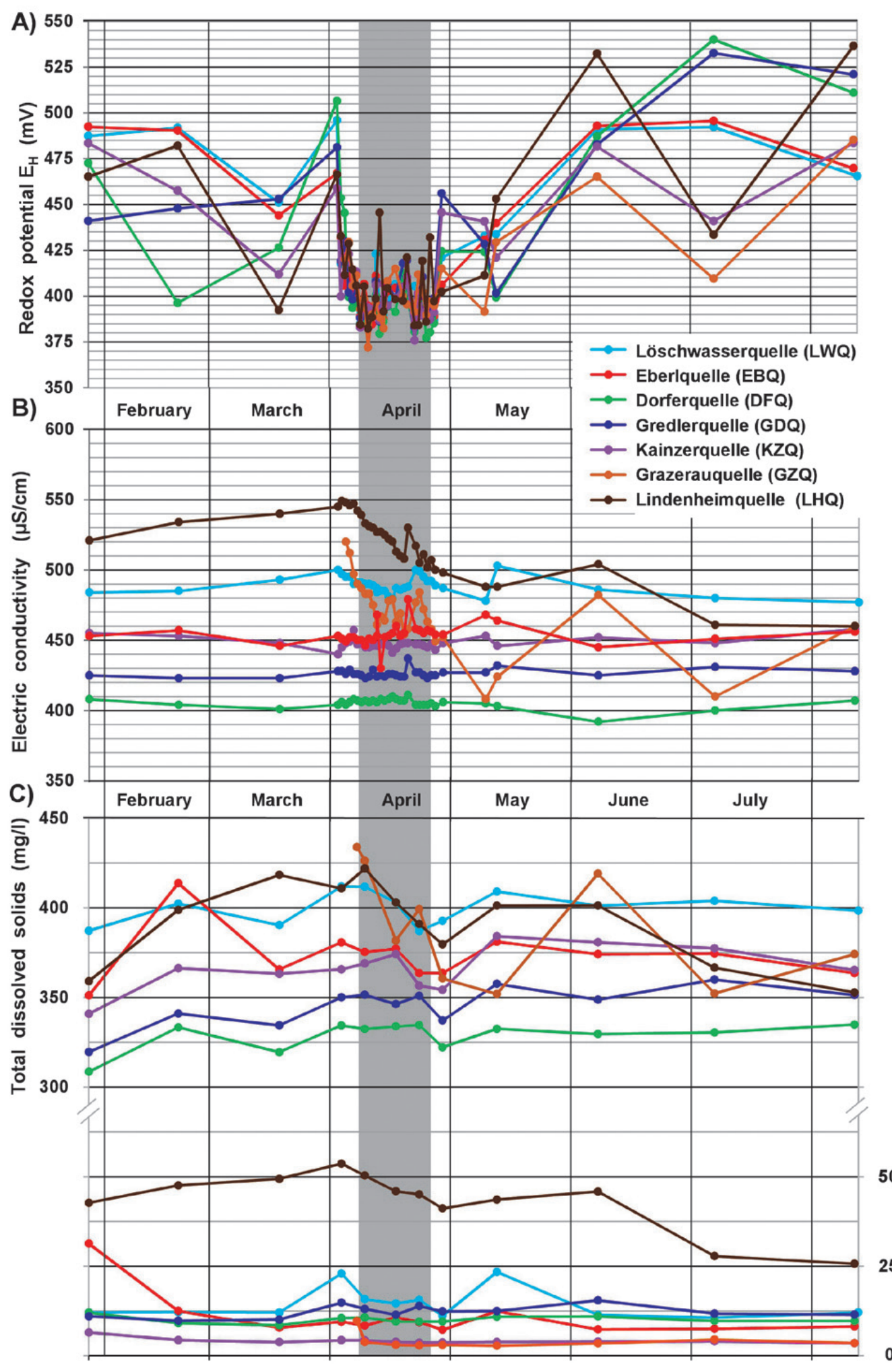

Fig. 4: Spring monitoring results from January to August 2013: A) redox potential, B) electrical conductivity related to $25^{\circ} \mathrm{C}$, C) total dissolved solids and summated sodium and chloride concentration. 
to 10.1 to $14.1{ }^{\circ} \mathrm{C}$ by June or July (Fig. 3B). The better data availability in April shows that water temperatures are not uniformly increasing but oscillating. Temperatures in August are lower than in June or July.

During the field work, an increase of discharge rates was observed a few hours after precipitation events began, while discharge starts to decrease immediately after dry periods. The largest percentages of discharge and temperature fluctuations are observed in Lindenheimquelle (LHQ). LHQ is intermittent while all other springs are perennial (Fig. 3C).

\section{REDOX POTENTIAL AND PH}

In all springs, one week before the beginning of the drilling works, redox potential declined abruptly from a range of 460 to $510 \mathrm{mV}$ to a range of 380 to $420 \mathrm{mV}$ (Fig. 4A). In late April and early May, redox potential began to rise and reached the prior level.

The $\mathrm{pH}$ fluctuates between 7.0 and 8.2 representing typical values for local groundwater.

\section{ELECTRICAL CONDUCTIVITY AND MINERALISATION}

Apart from Kainzerquelle (KZQ), elevated conductivity values are observed in all springs in the second half of April (Fig. 4B). In DFQ, GDQ, EBQ and GZQ, this (local) maximum was observed on April 20, in LHQ and LWQ on 23 April.

LWQ, KZQ, GDQ as well as DFQ have low variability in mineralization and electrical conductivity (Fig. 4B and $4 \mathrm{C}$ ). All spring waters are of a calcium-magnesium- bicarbonate-type, typical for shallow groundwater. The equivalent concentrations vary between 59 to $85 \% \mathrm{Ca}^{2+}$, 18 to $34 \% \mathrm{Mg}^{2+}$, 65 to $88 \% \mathrm{HCO}_{3}^{-}$and 6 to $23 \% \mathrm{SO}_{4}{ }^{2-}$. All other ions do not reach equivalent concentrations above $5 \%$, with the exception of $\mathrm{Na}^{+}(9-14 \%)$ and $\mathrm{Cl}^{-}$ (9 - 18\%) in Grazerauquelle (GZQ).

All waters are close to the lime-saturation limit or they are oversaturated in calcium carbonate. The highest calcium concentrations are observed in LHQ. Since LHQ has a very low discharge rate, tufa precipitates at this spring, driven by carbon dioxide degassing (Fig. 5). This finding supports the concept of lime-saturated groundwater with low karstification potential on the northern valley slope.

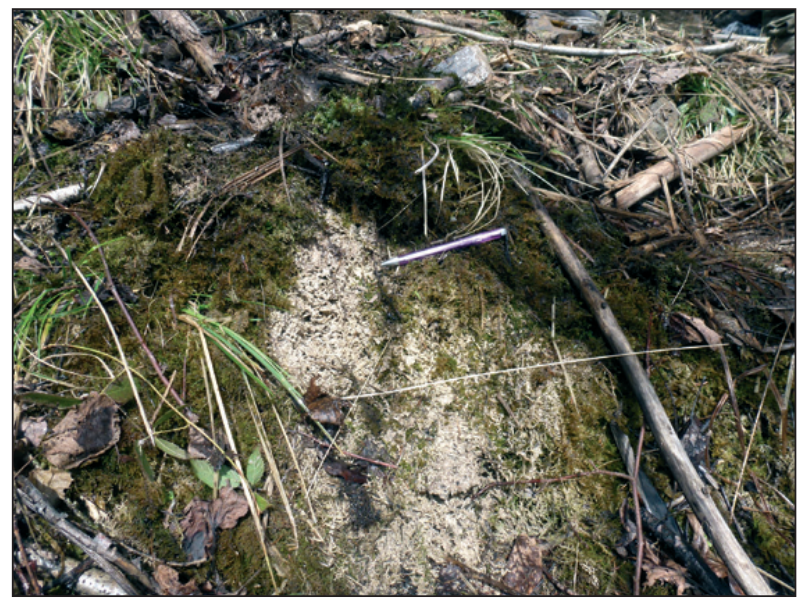

Fig. 5: Tufa at Lindenheimquelle in April 2013.

\section{DISCUSSION}

\section{TURBIDITY}

An increase of the spring water turbidity was found to be the most accurate indication of drilling fluid impact on groundwater quality. The first two peaks in LWQ occurred on the days after the grouting of BHEs 6 and 9, respectively (Fig. 3A). These elevated turbidities are associated with these boreholes. The third peak may be caused by well 8 , but was detected three days after the borehole cementation. Since BHE 9 is the closest to LWQ, it caused the highest peak. A much weaker signal from BHE 4 may have been obscured by this peak.

The meaning of the last peak, 2.0 FNU on 27 April, is vague. This turbidity value is within the natural variance, most likely originating from natural causes. However, the peak could also be related to completion of the wells $3,7,2$ or 5. In addition, correlating certain activities at specific BHEs is difficult, because two drill rigs were simultaneously under load.

Compared to LWQ, slightly lower turbidity values are expected at EBQ due to the greater distance to the drilling site. But the two peaks of EBQ are within the natural range. An association with the BHE is doubtful, especially because the main peak is missing in comparison to LWQ. DFQ is located above the borehole heat exchanger field, virtually excluding groundwater flow upstream into this direction (Fig. 2). Thus DFQ and GDQ peaks on 17 April are assigned to natural causes.

It became evident that the northern wellbores 6,8 and 9 have directly affected LWQ and hence proved to be in hydraulic contact with the spring. The wellbores 2, 3 
and 4 in a more southern position (Fig. 2) did not affect the water quality while they were being drilled or completed. This is likely also valid for wellbores 5 and 7 . The catchment areas of all other springs are evidently either too far north or too far away in order to be influenced by turbidity. This observation corresponds to the presumed groundwater flow in the uppermost part of the aquifer. The catchment areas are controlled by the topography and the strike of the Hochstegen Formation foliation of about $60^{\circ}$.

\section{WATER TEMPERATURE AND DISCHARGE}

The temperature pattern corresponds to the typical annual variation of shallow groundwater (Fig. 3B). The better data availability in April allows an interpretation in more detail. An expected correlation between discharge, precipitation, spring water temperature and air temperature occurs

Consequently, weather conditions are the determining factors of the documented temperature and discharge fluctuations. A temporary influence of the drilling work cannot be excluded completely, but is evaluated as insignificant compared to weather conditions.

The low discharge rate of LHQ might be a result of a small catchment causing sensitivity to weather changes as documented by the largest temperature variability and the largest discharge spread of all monitored springs (Fig. 3B and 3C).

\section{REDOX POTENTIAL AND PH}

The redox potential drop correlates well with the main phase of the snowmelt, which began in 2013 in April (cf. the trend of the air temperature in Fig. 3B) at the
Penken. After the end of the snowmelt in late April and early May the redox potential reached the previous level (Fig. 4A). The minima of the redox potential in March can be related to a previous heavy thawing event, lasting approximately one week. The variation in the redox potential is attributed to the weather and not to the drilling works.

Regarding $\mathrm{pH}$, seasonal trends or an impact of the drillings cannot be observed.

\section{ELECTRICAL CONDUCTIVITY AND MINERALISATION}

A correlation of the elevated electrical conductivity values in the second half of April with the sinking of the wellbores is rejected for two reasons. Firstly, the displayed peak pattern does not fit the drilling event, temporally or spatially. Secondly, a minor increase is also observed in the DFQ, the background measuring point. Unfortunately, which ions have caused the increased electrical conductivity cannot be clarified, as no samples were collected for laboratory analysis on 20 April.

The chemical composition is typical for groundwater from the Hochstegen Formation (Sass et al. 2016b). Grazerauquelle (GZQ) is located below the road from Mayrhofen to Hintertux (Fig. 2). The elevated amount of sodium and chloride probably correlates with road deicing services. Sodium and chloride concentrations in GZQ and the electrical conductivity, decrease after winter (Fig. 4B and 4C).

As discussed earlier, the fluctuations of LHQ are presumably due to the small catchment. The total dissolved solid value of EBQ in February is an outlier and is attributed to errors in the in situ titration.

\section{CONCLUSIONS}

\section{GEOTHERMAL EXPLOITATION OF KARST AQUIFERS}

The successful implementation of this project has shown that the construction of a shallow geothermal system in a karst aquifer is technically possible. The negative and permanent impact on groundwater quality perceived by water authorities was not found. We hope that this project encourages and stimulates geothermal use of karst aquifers and reduces public authorities' concerns regarding facilitating approval procedures.

After the first few years of operation, the system is running satisfactorily and an expansion of the borehole heat exchanger field is intended (Sass et al. 2016c). For this purpose a better understanding of the karstification and hydraulic anisotropy of the Hochstegen Formation is needed. This can be achieved, for example, by means of tracing experiments to clarify the catchment of the karst springs within the Tuxbach Gorge.

Usually pneumatic down hole hammer drilling is not used for carbonate rocks and such depths as here. However, this project showed that this drilling technology can still be used successfully under these conditions. Pneumatic down hole hammer drilling contributed to the low impact of the drilling on the groundwater and can be recommended for comparable applications. 


\section{SPRING MONITORING PROGRAM}

The spring monitoring program proved to be an adequate method to substantiate hydraulic contacts between the wellbores and natural springs. In terms of physical and chemical parameters, quantitative or qualitative changes have occurred. The permits for construction of the borehole heat exchangers in a karst aquifer were complicated to obtain. The authorities disagreed on how best to balance groundwater protection with climate friendly energy supply. The karst system has high geothermal potential. This prompted the unique karst exploration by drilling. Other approaches for shallow geothermal exploration can be found in Milenic and Vranjes (2014) and Milenic et al. (2016). The result was a new specific spring monitoring program. Additionally, communication of the monitoring results with the local population significantly helped to increase the public acceptance of the geothermal project. The spring monitoring was implemented with a comparatively low budget and temporal effort. It can therefore be recommended for related projects or questions, adapting the characteristic parameters to be collected and the measurement intervals in consultation with the responsible authorities.

\section{TURBIDITY AS TRACER}

A hydraulic connection between some bores and LWQ was able to be proved by the analysis of turbidity measurements. All other monitored physical and chemical parameters did not support this finding because the difference between natural background and anthropogenic input seems not to be large enough. Turbidity has proved to be a suitable tracer due to the difference in some orders of magnitude of the turbidity values between the groundwater and the drilling fluid. A short flow distance or travel time between drilling impact and sampling point is a likely prerequisite. However, in the setting of the construction project, tracers typically used in karsts appear to be unfeasible (Goldscheider et al. 2008) and other methods approved in boreholes are unpromising (Kogovšek \& Petrič 2010; Maurice et al. 2011, 2012).

\section{ACKNOWLEDGMENTS}

We thank Josef Stock and Sporthotel Stock Team, the voluntary fire brigade Finkenberg, Hotel Eberl and all other spring owners, Philipp Zimmermann, Gillian Wilson, Önder Aktulga (Montane Authority West, Federal Ministry of Science, Research and Economy) as well as
Michael Möderl (Tyrol Regional Authority of Water Management). We thank the editor and two anonymous reviewers for their constructive remarks, which helped to improve this paper.

\section{REFERENCES}

Bakalowicz, M., 2005: Karst groundwater: a challenge for new resources.- Hydrogeology Journal, 13, 148-160. DOI: http://dx.doi.org/10.1007/s10040-004-0402-9

Beil-Gregorczyk, F., 1988: Petrographie, Genese und stratigraphische Stellung des Porphyrmaterialschiefers am Nordrand des Tauernfensters zwischen Hintertux und Gerlospaß.- Jahrbuch der Geologischen Bundesanstalt, 131, 219-230.

Bundeskanzleramt, 1999: Mineralrohstoffgesetz - MinroG. Bundesgesetzblatt für die Republik Österreich I, 38/1999, 327-394.- [Online] Available from: https://www.ris.bka.gv.at/GeltendeFassung.wxe?Abfr age $=$ Bundesnormen $\&$ Gesetzesnummer $=10008040$ [Accessed $8^{\text {th }}$ February 2017].

Bundeskanzleramt, 2001: Verordnung des Bundesministers für soziale Sicherheit und Generationen über die Qualität von Wasser für den menschlichen Gebrauch (Trinkwasserverordnung - TWV). Bundesgesetzblatt für die Republik Österreich II, 304/2001, 1805-1822; last modification 208/2015.[Online] Available from: https://www.ris.bka.gv.at/ GeltendeFassung.wxe?Abfrage $=$ Bundesnormen $\& G$ esetzesnummer $=20001483$ [Accessed $28^{\text {th }}$ September 2017].

Butscher, C., Huggenberger, P., Auckenthaler, A. \& D. Bänninger, 2011: Risk-oriented approval of borehole heat exchangers.- Grundwasser, 16, 13-24. DOI: http://dx.doi.org/10.1007/s00767-010-0154-5

Christian, E. \& C. Spötl, 2010: Karst geology and cave fauna of Austria: a concise review.- International Journal of Speleology, 39, 71-90. DOI: http://dx.doi. org/10.5038/1827-806X.39.2.3 
Cliff, R., Spötl, C. \& A. Mangini, 2010: U-Pb dating of speleothems from Spannagel Cave, Austrian Alps: A high resolution comparison with $\mathrm{U}$-series ages.Quaternary Geochronology, 5, 452-458. DOI: http://dx.doi.org/10.1016/j.quageo.2009.12.002

EC, 1998: Council Directive 98/83/EC of 3 November 1998 on the quality of water intended for human consumption. Official Journal, L 330, 05/12/1998, 32-54.- [Online] Available from: http://eur-lex.europa.eu/eli/dir/1998/83/oj [Accessed $28^{\text {th }}$ September 2017].

Frisch, W., 1968: Zur Geologie des Gebietes zwischen Tuxbach und Tuxer Hauptkamm bei Lanersbach (Zillertal, Tirol). Mitteilungen der Gesellschaft der Geologie- und Bergbaustudenten, 18, 287-336.

Frisch, W., 1979: Tectonic progradation and plate tectonic evolution of the Alps.- Tectonophysics, 60, 121-139. DOI: http://dx.doi.org/10.1016/00401951(79)90155-0

Frisch, W., 1980: Post-Hercynian formations of the western Tauern window: sedimentological features, depositional environment, and age.- Mitteilungen der österreichischen geologischen Gesellschaft, 71$72,49-63$.

Geologische Bundesanstalt, 2005: Geological Map of Austria, Geofast 1:50 000, map sheet 149 - Lanersbach,Vienna, Edition 2011/09.

Goldscheider, N. \& N. Ravbar, 2010: Editoral: Research Frontiers and Practical Challenges in Karst Hydrogeology.- Acta Carsologica, 39, 169-172. DOI: http://dx.doi.org/10.3986/ac.v39i2.92

Goldscheider, N., Meiman, J., Pronk, M. \& C. Smart, 2008: Tracer tests in karst hydrogeology and speleology.- International Journal of Speleology, 37, 27-40. DOI: http://dx.doi.org/10.5038/1827-806X.37.1.3

Goldscheider, N., Mádl-Szönyi, J., Eröss, A. \& E. Schill, 2010: Review: Thermal water resources in carbonate rock aquifer.- Hydrogeology Journal, 18, 1303-1318. DOI: http://dx.doi.org/10.1007/ s10040-010-0611-3

Kießling, W., 1992: Palaeontological and facial features of the Upper Jurassic Hochstegen Marble (Tauern Window, Eastern Alps).- Terra Nova, 4, 184-197. DOI: http://dx.doi.org/10.1111/j.1365-3121.1992.tb00471.x

Kießling, W. \& A. Zeiss, 1992: New Palaeontological Data from the Hochstegen Marble (Tauern Window, Eastern Austria).- Geologisch Paläontologische Mitteilungen Innsbruck, 18, 187-202.

Kogovšek, J. \& M. Petrič, 2010: Tracer Testy as a Tool for Planning the Monitoring of Negative Impacts of the Mozelj Landfill (SE Slovenia) on Karst Waters. Acta Carsologica, 39, 301-311. DOI: http://dx.doi. org/10.3986/ac.v39i2.101
Kurz, W., Neubauer, F., Genser, J. \& E. Dachs, 1998: Alpine Geodynamic Evolution of passive and active continental margin sequences in the Tauern Window (eastern Alps, Austria, Italy): a review.- Geologische Rundschau, 87, 225-242. DOI: http://dx.doi. org/10.1007/s005310050204

Land Tirol, 2017: Tiris - Tiroler Rauminformationssystem 2.0.- [Online] Available from: https://www. tirol.gv.at/statistik-budget/tiris/ [Accessed $8^{\text {th }}$ February 2017].

Lehr, C. \& I. Sass, 2014: Thermo-optical parameter acquisition and characterization of geologic properties: a 400-m deep BHE in a karstic alpine marble aquifer.Environmental Earth Sciences, 72, 1403-1419. DOI: http://dx.doi.org/10.1007/s12665-014-3310-x

Maurice, L., Barker, J. A., Atkinson, T. C., Williams, A. T. \& P. L. Smart, 2011: A Tracer Methodology for Identifying Ambient Flows in Boreholes.- Ground Water, 49, 227-238. DOI: http://dx.doi.org/10.1111/ j.1745-6584.2010.00708.x

Maurice, L., Atkinson, T. C., Barker, J. A., Williams, A. T. \& A. J. Gallagher, 2012: The nature and distribution of flowing features in a weakly karstified porous limestone aquifer.- Journal of Hydrology, 438-439, 3-15. DOI: http://dx.doi.org/10.1016/j.jhydrol.2011.11.050

Milenic, D. \& A. Vranjes, 2014: Geothermal Potential and Sustainable Use of Karst Groundwater in Urban Areas - Belgrade, Capital of Serbia Case Study.Acta Carsologica, 43, 75-88. DOI: http://dx.doi. org/10.3986/ac.v43i1.749

Milenic, D., Stevanovic, Z., Dragisic, V., Vranjes, A. \& N. Savic, 2016: Application of renewable energy sources along motorway infrastructures on high karst plateaus: West Serbia case study-. Environmental Earth Sciences, 75, 859. DOI: http://dx.doi. org/10.1007/s12665-016-5635-0

Misstear, B., Banks, D. \& L. Clark, 2006: Water Wells and Boreholes.- Wiley. pp. 498, Chichester.

Rauch, T. \& G. Neuner, 1993: Rutschung Finkenberg: Bericht zur geologisch-geomorphologischen Kartierung des Penken Südhanges. Geologische Bundesanstalt, Vienna, Report number: A 09486.

Rosenberg, C. L. \& S. Schneider, 2008: The western termination of the SEMP Fault (eastern Alps) and its bearing on the exhumation of the Tauern Window.Geological Society of London Special Publication, 298, 197-218. DOI: http://dx.doi.org/10.1144/ SP298.10

Sass, I., Heldmann, C.-D. \& C. Lehr, 2016a: Exploitation of a Marble Karst Reservoir for a medium deep Borehole Heat Exchange System in Tux, Tyrol.Grundwasser, 21, 137-145. DOI: http://dx.doi. org/10.1007/s00767-016-0327-y 
Sass, I., Heldmann, C.-D. \& R. Schäffer, 2016b: Exploration and monitoring for geothermal exploitation of an Alpine karst aquifer, Tux valley, Austria.- Grundwasser, 21, 147-156. DOI: http://dx.doi.org/10.1007/ s00767-015-0312-x

Sass, I., Lehr, C., Egert, R., Heldmann, C.-D. \& R. Schäffer, 2016c: Optimizing design parameters for middle deep borehole exchanger storage systems.In: H. Ortner (ed.) Abstract Volume of GeoTirol2016 - Annual Meeting of DGGV and PANGEO Austria, 25th-28th September 2016, Innsbruck. Institute of Geology, University of Innsbruck, 297, Innsbruck.

Schmid, S. M., Scharf, A., Handy, M. R. \& C. L. Rosenberg, 2013: The Tauern Window (Eastern Alps, Austria): a new tectonic map, with cross-sections and a tectonometamorphic synthesis.- Swiss Journal of Geosciences, 106, 1-32. DOI: http://dx.doi. org/10.1007/s00015-013-0123-y

Spötl, C., 2009: Höhlen im Gebiet des Höllensteins, Tuxertal (Tirol).- Höhlenkundliche Mitteilungen, 61, 7-16.

Spötl, C. \& A. Mangini, 2010: Paleohydrology of a highelevation, glacier-influenced karst system in the Central Alps (Austria).- Austrian Journal of Earth Sciences, 103, 92-105.

Spötl, C. \& A. Schiffmann, 2014: Zwei aktive Kleinhöhlen in der Klamm des Tuxbaches in Finkenberg.- Höhlenkundliche Mitteilungen, 66, 19-22.
Stevanović, Z. \& P. Milanović, 2015: Engineering Challenges in Karst.- Acta Carsologica, 44, 381-399. DOI: http://dx.doi.org/10.3986/ac.v44i3.2963

Stummer, G. \& L. Plan, 2002: Speldok-Austria, Handbuch zum Österreichischen Höhlenverzeichnis.- [Online] Available from: http://hoehle.org/downloads/ SD_10_Handbuch.pdf [Accessed 21 ${ }^{\text {st }}$ March 2017].

Thiele, O., 1976: Der Nordrand des Tauernfensters zwischen Mayrhofen und Inner Schmirn (Tirol).Geologische Rundschau, 65, 410-421. http://dx.doi. org/10.1007/BF01808473

Veselá, P., Söllner, F., Finger, F. \& A. Gerdes, 2011: Magmato-sedimentary Carboniferous to Jurassic evolution of the western Tauern window, Eastern Alps (constraints from $\mathrm{U}-\mathrm{Pb}$ zircon dating and geochemistry).- International Journal of Earth Sciences, 100, 993-1027. DOI: http://dx.doi.org/10.1007/s00531010-0596-0

Wirsig, C., Zasadni, J., Christl, M., Akçar, N. \& S. IvyOchs, 2016: Dating the onset of LGM ice surface lowering in the High Alps.- Quaternary Science Review, 143, 37-50. DOI: http://dx.doi.org/10.1016/j. quascirev.2016.05.00 